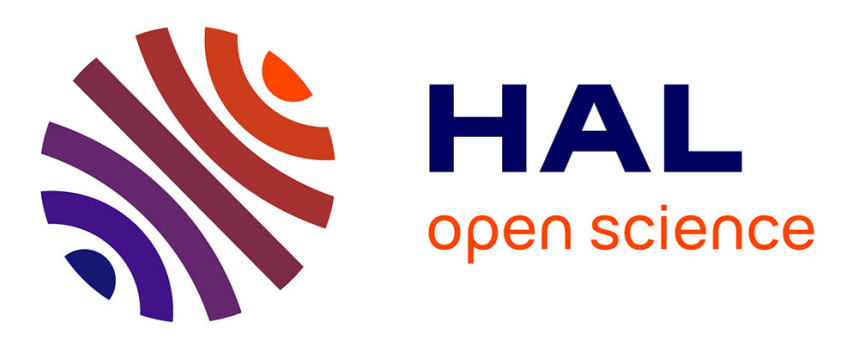

\title{
A fullerene helical peptide: synthesis, characterization and formation of self-assembled monolayers on gold surfaces
}

Houssein Nasrallah, Jad Rabah, Van Bui-Thi-Tuyet, Krystyna Baczko, Hélène Fensterbank, Flavien Bourdreux, Anne-Marie Goncalves, Valérie Declerck, Souhir Boujday, Vincent Humblot, et al.

\section{To cite this version:}

Houssein Nasrallah, Jad Rabah, Van Bui-Thi-Tuyet, Krystyna Baczko, Hélène Fensterbank, et al.. A fullerene helical peptide: synthesis, characterization and formation of self-assembled monolayers on gold surfaces. New Journal of Chemistry, 2018, 42 (24), pp.19423-19432. 10.1039/c8nj04599b . hal-02348881

\section{HAL Id: hal-02348881 \\ https://hal.science/hal-02348881}

Submitted on 22 Jan 2021

HAL is a multi-disciplinary open access archive for the deposit and dissemination of scientific research documents, whether they are published or not. The documents may come from teaching and research institutions in France or abroad, or from public or private research centers.
L'archive ouverte pluridisciplinaire $\mathbf{H A L}$, est destinée au dépôt et à la diffusion de documents scientifiques de niveau recherche, publiés ou non, émanant des établissements d'enseignement et de recherche français ou étrangers, des laboratoires publics ou privés. 


\section{Fullerene Helical Peptide: Synthesis, Characterization and Formation of Self-Assembled Monolayers on gold surfaces}

Houssein Nasrallah, ${ }^{[\mathrm{a}]} \mathrm{Jad}$ Rabah, ${ }^{[\mathrm{a}]}$ Van Bui-Thi-Tuyet, ${ }^{[\mathrm{a}]}$ Krystyna Baczko, ${ }^{[\mathrm{a}]}$ Hélène Fensterbank, ${ }^{[a]}$ Flavien Bourdreux, ${ }^{[a]}$, Anne-Marie Goncalves, ${ }^{[\mathrm{a}]}$ Valérie Declerck, ${ }^{[\mathrm{b}]}$ Souhir Boujday, ${ }^{[c]}$ Vincent Humblot, ${ }^{[c]}$ Karen Wright, ${ }^{*[a]}$ Anne Valleee, ${ }^{*[a]}$ and Emmanuel Allard ${ }^{*[a]}$

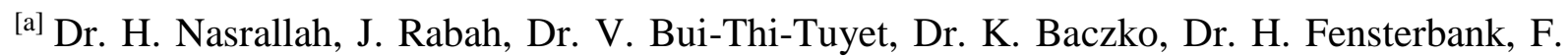
Bourdreux, Dr.A-M. Goncalves, ${ }^{[a]}$ Dr. K. Wright, Dr. A. Vallée, Dr. E. Allard

ILV, UMR-CNRS 8180

Université de Versailles-Saint-Quentin-en-Yvelines, 45 avenue des Etats-Unis, 78035 Versailles cedex (France)

${ }^{[b]}$ Dr. V. Declerck

CP3A Organic Synthesis Group, ICMMO, UMR-CNRS 8182

Université Paris Sud, Université Paris-Saclay

15 rue Georges Clemenceau 91405 Orsay cedex (France)

${ }^{[c]}$ Dr. S. Boujday, Dr. V. Humblot

Sorbonne Université,

UMR-CNRS 7197, Laboratoire de Réactivité de Surface (LRS),

4 Place Jussieu, F-75005 Paris (France)

\section{Abstract}

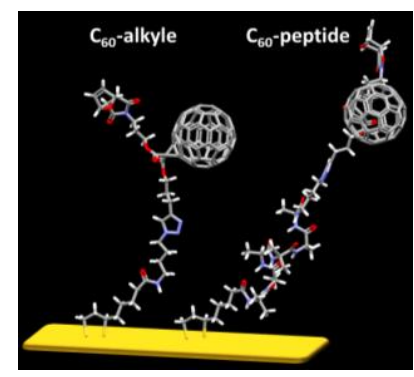

The synthesis of a C60-peptide using "clickable" fullerene and peptide derivatives is described. The peptide is composed of a repeating sequence of $\alpha$-aminoisobutyric acid (Aib) and two LAlanine (Ala) residues, promoting the formation of a helical conformation, which has been confirmed by IR absorption, NMR and circular dichroism measurements. In addition, the presence of a lipoyl moiety, at the end of the peptide sequence, allows the formation of selfassembled monolayers of $\mathbf{C}_{60}$-peptide and the parent peptide on a gold surface. A $\mathbf{C}_{60}$-alkyl derivative was also prepared to compare the self-assembling properties of fullerene derivatives containing peptide or alkyl chains. The fullerene assembly on a gold substrate characterized by quartz crystal microbalance and by cyclic voltammetry show that the monolayers containing the alkyl chains are slightly less well packed than the peptide monolayers. Finally, polarization modulation reflection adsorption infra-red spectroscopy measurements indicate that the $\mathbf{C}_{60}$ - 
peptide tend to be more vertical than the parent peptide which could originate from complementary $\mathbf{C}_{60}-\mathbf{C}_{60}$ and helical-helical interactions.

\section{Introduction}

Since their discovery, fullerene $\mathrm{C}_{60}$ and its derivatives have attracted the interest of many researchers due to their outstanding physical and chemical properties, that have promising applications in the fields of life and materials sciences. In particular, the surface modification with $\mathrm{C}_{60}$-based thin films or monolayers allows the transfer of their unique properties to solid surfaces, which may lead to practical applications especially in organic electronics. The main methods to prepare monolayers or thin films of fullerene are based on the Langmuir and Langmuir-Blodgett deposition techniques, as well as the formation of self-assembled monolayers (SAMs) on solid surfaces. ${ }^{[1-2]}$ The latter approach has attracted much attention, since self-assembled monolayers are spontaneously formed by chemisorption, giving rise to robust and well-defined structures on solid surfaces. ${ }^{[2]}$ Fullerene $\mathrm{C}_{60}$-based self-assembled monolayers have been involved in the fabrication of solar cells as the electron selective layer, noticeably improving the efficiency of the device, ${ }^{[3]}$ in field-effect transistors ${ }^{[4]}$ as well as in molecular rectifiers. ${ }^{[5]}$ The immobilization of donor-fullerene systems on surfaces for the construction of photoelectrochemical devices has also been considered. ${ }^{[6]}$ The occurrence of photo-induced energy and/or electron transfer in these donor-fullerene systems was used to generate photocurrent. More recently, it was proposed that the charge separated state formed after illumination of donor-fullerene SAMs could also function as a hole-blocking and an electron transporting layer for photovoltaic cell applications. ${ }^{[7]}$

The design of [60]Fullerene-based self-assembled monolayers on a variety of substrates, in particular gold conductive surfaces, has been extensively studied. ${ }^{[8]}$ Among the approaches that have been proposed to form SAMs containing fullerene $\mathrm{C}_{60}$ on gold surfaces, the direct strategy yields the most stable as well as the most homogeneous monolayers. ${ }^{[2]}$ This method relies on the use of $\mathrm{C}_{60}$ derivatives fitted with anchoring units such as thiols or disulfides, that are well-known to bind strongly to gold surfaces. ${ }^{[9]}$ Usually, the fullerene $\mathrm{C}_{60}$ and its sulfur anchoring unit are connected by a spacer, including alkyl chains and $\pi$-conjugated systems. Very often in the literature, SAMs of molecular assemblies including fullerene derivatives are depicted as idealized representations without defects. However, Tour and coworkers have shown that the immobilization of fullerene $\mathrm{C}_{60}$ on gold surfaces leads to binding anomalies where the desired monolayers can coexist with multi-layers and/or head-to-tail assemblies. ${ }^{[10]}$ These anomalies could modify the properties of the devices, thereby limiting the use of $\mathrm{C}_{60}-\mathrm{SAMs}$ in a number of applications.

In this context, we propose to use peptides as surface structuring agents, as it has been shown that peptides adopting a helical conformation in solution and in the solid state may form well-organized and compact monolayers. Moreover, the diameter of the fullerene $\mathrm{C}_{60}{ }^{[2]}$ and of a peptide helix, whatever its nature $\left(3_{10}\right.$ or $\alpha$-helix), ${ }^{[11]}$ are of the same order of magnitude (close to $1.0 \mathrm{~nm}$ ). In this case, organization within the monolayer should be governed by two types of interactions, $\mathrm{C}_{60}-\mathrm{C}_{60}$ and peptide-peptide interactions, which could lead to a reduction in head- 
to-tail anomalies. In addition, a helical peptide appears to be a good electron mediator compared to an alkyl chain. Electron transfer through a peptide bridge is also strongly asymmetric, as transfer along the dipole moment in a helical peptide is much faster than against the dipole moment. These properties could be very important for organic electronic applications, especially for the design of electron selective interfaces, in electrochemical photocurrent generation as well as in molecular rectifiers.

The combination of peptides and $\mathrm{C}_{60}$ has been largely explored, mainly for biological applications and in the field of material science. ${ }^{[12,13]}$ However, immobilization of $\mathrm{C}_{60}$-peptides on surfaces in which the peptide adopts an helical conformation has been scarcely studied. To our knowledge, only one example has been reported by Kimura. In this study, porphyrin- and fullerene-terminated 16-mer helical peptides were used to form homogeneous binary SAMs. The formation and characterization of homogeneous SAMs based exclusively on fullerene terminated peptides were not reported in this paper. ${ }^{[14]}$

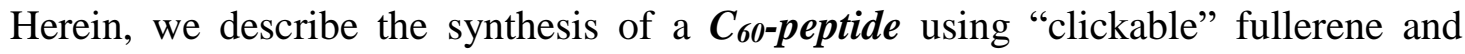
peptide derivatives. The fullerene building block bears an alkyne moiety and a protected maleimide. This derivative can be easily functionalized with azido and thiol derivatives after deprotection of the maleimide, ${ }^{[15]}$ which represents a significant advantage over previously used derivatives that allow grafting of only one unit. ${ }^{[14]}$ Moreover, we used a simple hexapeptide containing the repeating sequence $\alpha$-aminoisobutyric acid $(\boldsymbol{A i b})$ and two L-Alanine (Ala) residues. The choice of the peptide length, its composition and the position of the Aib residues in the sequence were determined by the conformational properties of $\mathrm{C}^{\alpha}$-tetrasubstituted amino acids, known to promote the formation of $3{ }_{10}$-helical structures in very short peptides. ${ }^{[16]}$ This hexapeptide carries a lipoyl moiety (at the N-terminus) to act as a bidendate ligand on the gold surface, and an azide moiety (at the C-terminus) allowing a copper-catalyzed alkyne-azide 1,3dipolar cycloaddition (CuAAC) reaction with the fullerene building block. The CuAAC reaction is a very powerful synthetic tool in fullerene chemistry, which has allowed the efficient synthesis of a variety of fullerene derivatives, some of which cannot be obtained by classical methods. ${ }^{[17]}$ This approach allows the grafting of our fullerene building block to the peptide in one step, unlike previous strategies in which multiple steps were necessary to complete the required fullerene-peptide conjugates. ${ }^{[14]}$ In addition, a reference compound $\left(\boldsymbol{C}_{\boldsymbol{6 0}}\right.$-alkyl$)$, in which an alkyl chain replaced the peptide, was also prepared in order to compare the selfassembling properties of their corresponding fullerene derivatives. The SAMs of starting Peptide, $\boldsymbol{C}_{60}$-alkyl and $\boldsymbol{C}_{60}$-peptide were then immobilized on a gold surface and their properties were studied using surface characterization and electrochemical techniques.

\section{Results and Discussion}

\section{Synthesis}

The fullerene building block $\mathbf{5}$ was prepared in a similar way as our previously reported fullerene platform, developed for sequential orthogonal transformations (Scheme S1) ${ }^{[15]}$ The alkyl spacer between the alkyne moiety and the $\mathrm{C}_{60}$ unit is shorter than in the previously described platform, in order to reduce the $\mathrm{C}_{60}$-surface distance in the final assembly. In the 
present $\mathrm{C}_{60}$ derivative, the maleimide moiety was introduced but remained protected. The lipoyl azide 7 was prepared in three steps from 4-aminobutanol. Reaction with hydrogen bromide followed by substitution with sodium azide gave the azido amine ${ }^{[18]}$ which was then coupled with $(R)$-lipoic acid in the presence of HATU (Scheme S2). The hexapeptide 15 was synthesised step-by-step in solution (Scheme S3), using O-(7-azabenzo-1,2,3-triazol-1-yl)1,1,3,3-tetramethyluronium hexafluorophosphate (HATU) as the coupling reagent and an $N^{\alpha}$ Boc protecting group strategy. The $C$-terminal alkyl azide chain was introduced by reaction of $N$-Boc-alanine succinimide ester with 4-aminobutanol, followed by mesylation and substitution with sodium azide, to give the desired protected azido-amide 9. Peptide chain elongation was performed by sequential deprotection of the $N$-terminal Boc group with trifluoroacetic acid and coupling of the following amino acid residue in the presence of HATU. The hexapeptide was finally substituted with $(R)$-lipoic acid at its $N$-terminal.

Reaction conditions for the copper-catalyzed alkyne-azide cycloaddition (CuAAC) reaction between the fullerene alkyne and the peptide azide or alkyl azide were investigated. Since the presence of sulfur atoms in substrates may lead to partial deactivation of the CuAAC catalytic system, ${ }^{[15 a, 19]}$ we performed preliminary experiments using copper (I) salts and various ligands in dichloromethane to determine the optimum conditions. From these experiments, it appeared that the best yields were obtained with bulky ligands such as (Hexabenzyl)Tren ${ }^{\text {[20] }}$ and tris-(benzyltriazolylmethyl)amine (TBTA). ${ }^{[21]}$ The preferred conditions for the CuAAC reaction between the alkyne $\mathrm{C}_{60}$ derivative 5 and the azide-peptide $\mathbf{1 5}$ or lipoyl azide 7 used the pre-formed complex $[\mathrm{Cu}(\mathrm{I})$ ligand (Hexabenzyl)Tren) $] \mathrm{Br}$, prepared from $\mathrm{CuBr}$ and the hexabenzylTren ligand, in dichloromethane at room temperature under an inert atmosphere (Scheme 1). The fullerene-alkyl and fullerene-peptide adducts were isolated in $40 \%$ and 60\% yields respectively, consistent with previous results obtained for this type of derivatization. This approach allowed the preparation of a significant amount of both the fullerene building block, the fullerene-alkyl adduct and the fullerene-peptide, and appears higher yielding than the previously reported method. ${ }^{[14]}$ Complete characterization of these derivatives using NMR and mass spectrometry was carried out. ${ }^{[22,23]}$ 

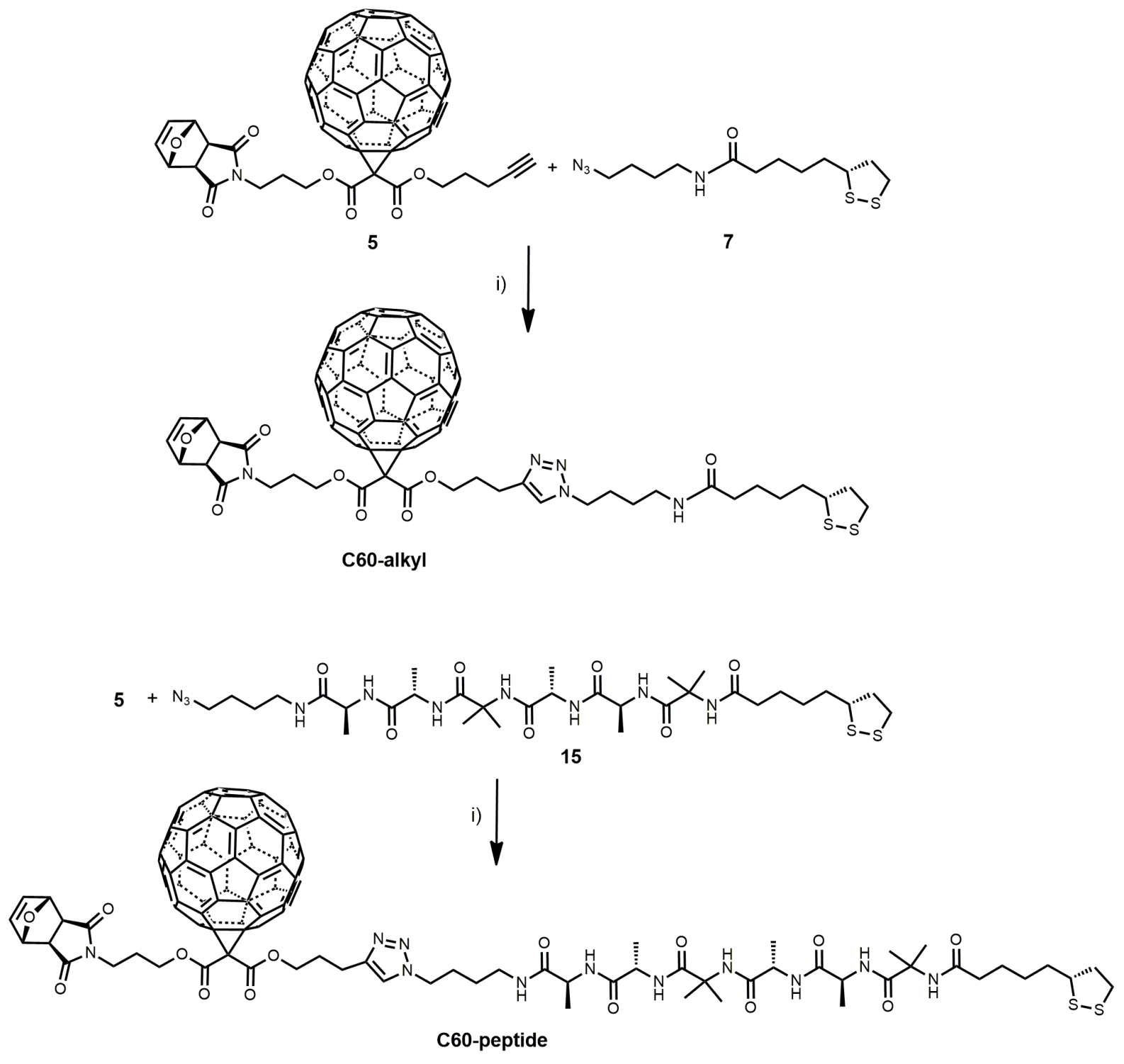

Scheme 1. Preparation of $\mathbf{C}_{60}$-alkyl and $\mathbf{C}_{60}$-peptide. Reagents and conditions: i) $\mathrm{CuBr}$, HexabenzylTren, $\mathrm{CH}_{2} \mathrm{Cl}_{2}$, rt, Ar atmosphere, 2 days ( $\mathbf{C}_{60}$-alkyl : 40\%; $\mathbf{C}_{60}$-peptide : 60\%).

\section{Solution conformational analysis}

The solution conformation of the reference hexapeptide15 and of the $\mathbf{C}_{60}$-peptide was studied by using a combination of infra-red absorption, NMR and by circular dichroism measurements.

IR Absorption Spectroscopy The FT-IR spectra of the hexapeptide 15 and of $\mathbf{C}_{60}$-peptide were recorded in $\mathrm{CDCl}_{3}$ at a concentration of $1 \mathrm{mM}$. The absorption bands of the two derivatives are located at the same position in the amide $\mathrm{A}$ and amide I region, indicating as previously reported that the conformation of the peptide is not modified by the presence of the $\mathrm{C}_{60}$ unit. ${ }^{[24]}$ In the N$\mathrm{H}$ stretching region (Figure S1), the FT-IR spectra show a strong absorption band at $3315 \mathrm{~cm}^{-1}$ ( $\mathrm{N}-\mathrm{H}$ groups in intramolecular $\mathrm{C}=\mathrm{O}---\mathrm{H}-\mathrm{N}$ hydrogen bonds) and a weaker band at $3430 \mathrm{~cm}^{-1}$ (free N-H groups). The amide I region (Figure S2) of the derivatives shows a strong absorption band with its maximum at $1655-1660 \mathrm{~cm}^{-1}$, in keeping with carbonyl stretching of a peptide 
adopting an helical conformation. However, it is difficult to determine the nature of the helix using this technique since the absorption maximum of a 310 -helix and $\alpha$-helix are close, in the $1666-1663 \mathrm{~cm}^{-1}$ and $1663-1658 \mathrm{~cm}^{-1}$ region, respectively. ${ }^{[25]}$ While the carbonyl stretching band is located in the $\alpha$-helix region, the 310 -helix conformation may also contribute in our short peptide structures.

${ }^{1} H$ NMR Spectroscopy The NMR analysis of the starting hexapeptide 15 was carried out in $\mathrm{CDCl}_{3}$ at a concentration of $50 \mathrm{mM}$ (see below) using a combination of COSY and ROESY experiments (Figures S3, S5-S7). The use of these complementary 2D experiments allowed the complete assignment of all proton resonances. The cross peaks observed in the ROESY spectrum between $\mathrm{NH}-\mathrm{NH}(\mathrm{i} \rightarrow \mathrm{i}+1)$ protons permitted the identification of all the amide protons of the peptide. These $\mathrm{NH}-\mathrm{NH}(\mathrm{i} \rightarrow \mathrm{i}+1)$ and some $\alpha \mathrm{H}-\mathrm{NH}(\mathrm{i} \rightarrow \mathrm{i}+1)$ interactions also indicate that the peptide adopts a prevailing folded structure. To complement the 2D experiments, DMSO- $\mathrm{d}_{6}$ titrations were performed on $1 \mathrm{mM}$ solutions of the hexapeptide 15 in $\mathrm{CDCl}_{3}$ (Figures 1 and S11). Similar titration experiments have already been used to verify that peptides containing Aib moieties adopt a 310 -helical conformation in solution. ${ }^{[26]}$ Upon the addition of the hydrogen bond acceptor DMSO- $\mathrm{d}_{6}$, the two amide $\mathrm{NH}$ protons of the Aib and Ala residues at the $1^{\text {st }}$ and $2^{\text {nd }}$ positions from the $\mathrm{N}$-terminus (denoted as $\mathrm{N}(\mathrm{I}) \mathrm{H}$ and $\mathrm{N}(\mathrm{II}) \mathrm{H}$ ) underwent significant downfield shifts ( $\Delta \delta=1.25$ and $0.47 \mathrm{ppm}$, respectively) while the other amide protons displayed minimal shifts $(\Delta \delta=0.05$ to $0.19 \mathrm{ppm})$. This suggests a 310 -helical conformation in solution where most $\mathrm{NH}$ groups (from $\mathrm{N}(\mathrm{III}) \mathrm{H}$ onward) are in a stable, intramolecular H-bonding network, while the two $\mathrm{NH}$ groups closest to the $\mathrm{N}$-terminus are exposed to intermolecular interactions. In addition, the concentration-dependence of ${ }^{1} \mathrm{H}$ NMR resonances of the amide $\mathbf{N H}$ groups of $\mathbf{1 5}$ in $\mathrm{CDCl}_{3}$ was examined (Figures $\mathbf{2}$ and S9). Such experiments have already been used to study the aggregation of helical peptides in non-polar aprotic media. ${ }^{[27]}$ As previously reported, the concentration-dependence study followed the trend observed during the DMSO dilution studies, with the $\mathrm{N}(\mathrm{I}) \mathrm{H}$ and $\mathrm{N}(\mathrm{II}) \mathrm{H}$ protons that are more involved in intermolecular interactions undergoing significant shifts as the concentration was raised from 1 to $100 \mathrm{mM}$ ( $\Delta \delta=1.51$ and $1.17 \mathrm{ppm}$, respectively), while the other $\mathrm{NH}$ protons, involved in the H-bonding network, showed smaller shifts $(\Delta \delta=0.03$ to $0.23 \mathrm{ppm}$, respectively). 


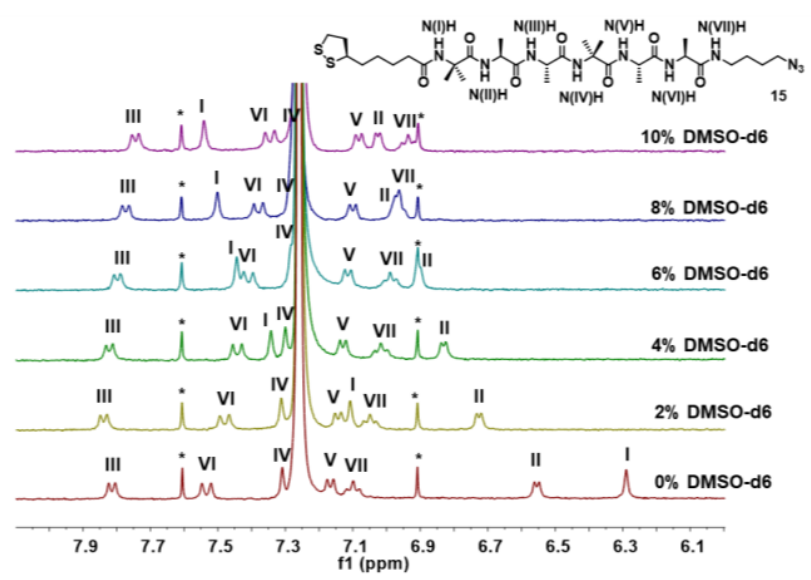

Figure 1. Stack plot of partial ${ }^{1} \mathrm{H}$ NMR spectra in which DMSO-d6 was added in a $1 \mathrm{mM}$ solution of the peptide 15 in $\mathrm{CDCl}_{3}(300 \mathrm{MHz}, 298 \mathrm{~K})$. The peaks labelled with an asterisk are due to satellite bands.

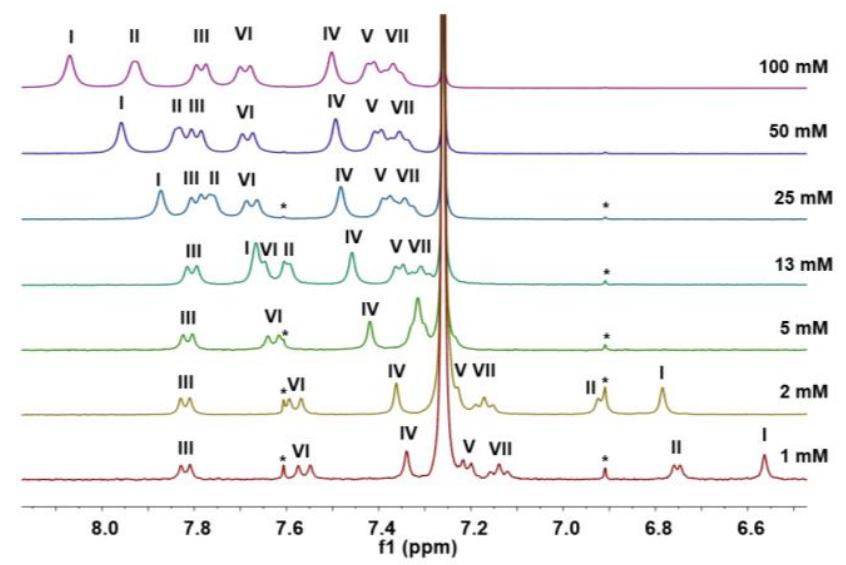

Figure 2. Stack plot of partial ${ }^{1} \mathrm{H}$ NMR spectra of peptide $\mathbf{1 5}$ taken at varying concentration from $1 \mathrm{mM}$ to $100 \mathrm{mM}$ (300 MHz, $\left.\mathrm{CDCl}_{3}, 298 \mathrm{~K}\right)$. The peaks labelled with an asterisk are due to satellite bands.

For the $\mathbf{C}_{60}$-peptide, NMR analyses were performed in $\mathrm{CDCl}_{3}$ at a concentration of $30 \mathrm{mM}$ (Figure S3). These experiments allowed the complete assignment of all proton resonances except those belonging to the amide protons, as some were too close to allow clear identification using the ROESY experiment. In order to assign the amide protons and to confirm the helical conformation of the $\mathbf{C}_{60}$-peptide, NMR experiments were further conducted in $\mathrm{C}_{5} \mathrm{D}_{5} \mathrm{~N}$ for this compound, along with the reference hexapeptide 15 (Figures S14-S21). For both compounds, the amide protons are well-dispersed and well-defined (Figures 3-4). The use of complementary 2D experiments (COSY, NOESY and ROESY) allowed the complete assignments of all proton resonances for $\mathbf{1 5}$ and $\mathbf{C}_{60}$-peptide. In particular, the NOESY spectrum of 15 showed two $\alpha \mathrm{H}-\mathrm{NH}(\mathrm{i} \rightarrow \mathrm{i}+2)$ cross peaks, suggesting specifically a 310 -helical structure. In addition, the cross peaks observed in the ROESY spectrum of $\mathbf{C}_{60}$-peptide between $\mathrm{NH}-\mathrm{NH}(\mathrm{i} \rightarrow \mathrm{i}+1)$ protons demonstrated that the peptide adopts a similar prevailing, likely helical, conformation as the reference hexapeptide15. 


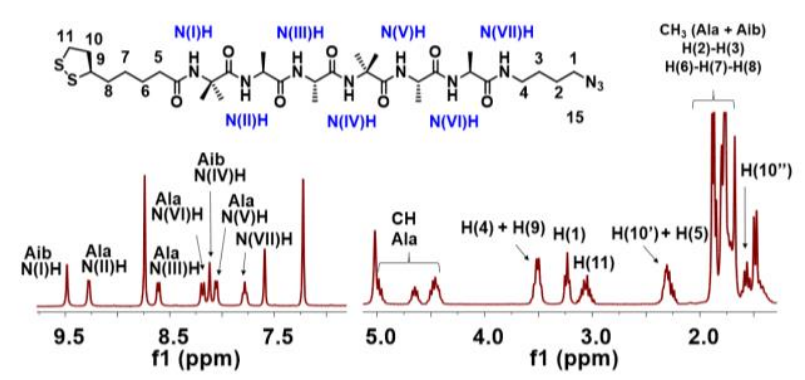

Figure 3. ${ }^{1} \mathrm{H}$ NMR spectrum of $\mathbf{1 5}$ in $\mathrm{C}_{5} \mathrm{D}_{5} \mathrm{~N}(300 \mathrm{MHz}, 298 \mathrm{~K})$.
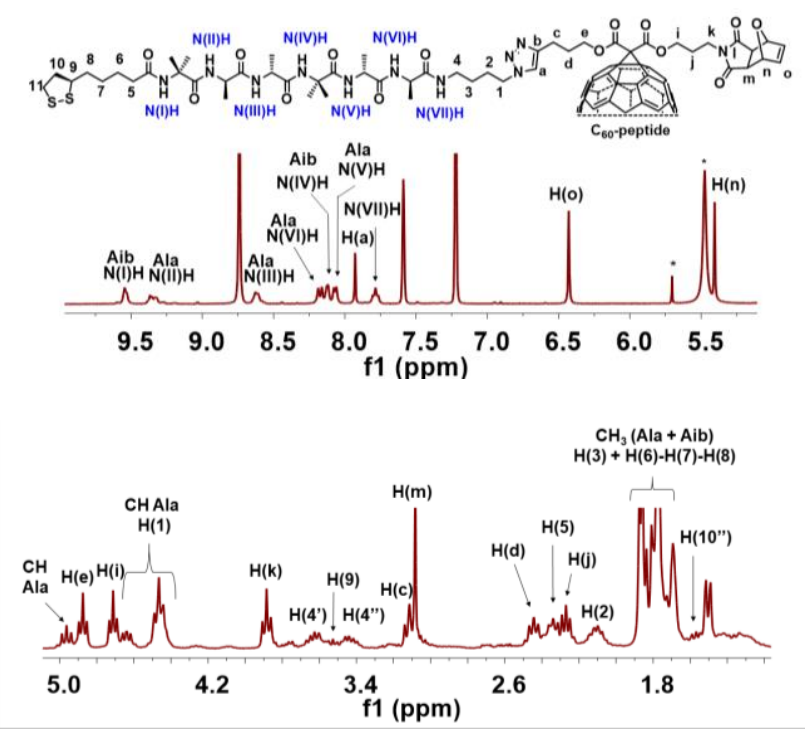

Figure 4. ${ }^{1} \mathrm{H}$ NMR spectrum of $\mathbf{C}_{60}$-peptide in $\mathrm{C}_{5} \mathrm{D}_{5} \mathrm{~N}(300 \mathrm{MHz}, 298 \mathrm{~K})$. The peaks labelled with an asterisk are due to solvent residues.

Circular Dichroism A far-UV CD spectrum of the hexapeptide 15 was acquired in $\mathrm{MeOH}$ solution (Figure S22). A strong negative Cotton effect at $203 \mathrm{~nm}$ was observed. It is widely recognised that negative Cotton effects below $200 \mathrm{~nm}$ (peptide $\pi$ - $\pi^{*}$ transition) indicate an unordered peptide conformation, while this band is shifted in peptides folded into helical conformations to $203-208 \mathrm{~nm} .{ }^{[28]}$ These results suggest an at least partially helical conformation for 15, consistent with previous studies of short Aib-containing peptides. ${ }^{[29]}$

\section{Self-Assembled Monolayer formation and Characterization}

The $\mathbf{C}_{60}$-peptide and $\mathbf{C}_{60}$-alkyl were self-assembled on gold surfaces by exposing a gold coated glass substrate to a solution of $\mathbf{C}_{60}$-peptide and $\mathbf{C}_{60}$-alkyl in dichloromethane. To determine the contribution of the peptide to the quality of the fullerene SAM, the SAMs were characterized in depth.

Cyclic Voltammetry $(C V)$ The molecular packing of the fullerene SAMs was evaluated by CV (blocking) experiments using bare and modified gold substrates as the working electrode. Figure 5 shows the $\mathrm{CV}$ responses of $\mathrm{K}_{3}\left[\mathrm{Fe}(\mathrm{CN})_{6}\right]$ aqueous solution on the different substrates. The peaks for the ferricyanide/ferrocyanide redox signal are clearly observed for the naked gold 
while these peaks are nearly abolished for the gold surface functionalized with $\mathbf{C}_{60}$-peptide molecules, highlighting the compactness of the $\mathbf{C}_{60}$-peptide SAM. In contrast, in the case of the C60-alkyl SAM the signal is lower than with naked gold but is still present. The gold surface is accessible to the redox probe which implies that the $\mathbf{C}_{60}$-alkyl molecules formed a less dense monolayer than C60-peptide molecules. ${ }^{[30]}$

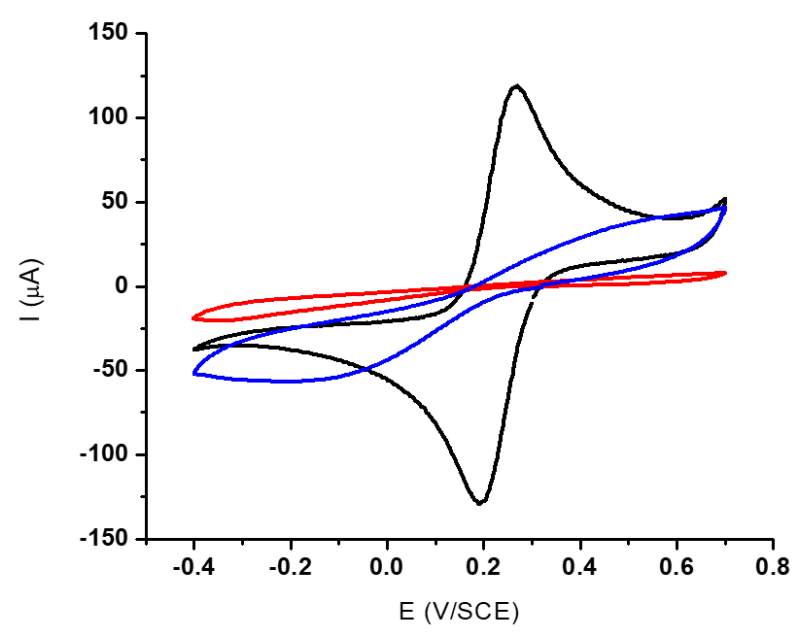

Figure 5 : $\mathrm{CVs}$ of $\mathrm{K}_{3}\left[\mathrm{Fe}(\mathrm{CN})_{6}\right]$ for naked gold electrode (black), C60-alkyl (blue) and $\mathbf{C}_{60}$ peptide (red) SAMs on a gold electrode.

Quartz Crystal Microbalance (QCM) To monitor the assembly of fullerene derivatives on gold surfaces, QCM measurements were performed in-situ using dichloromethane as solvent (Figure 6). The amount of C60-peptide and C60-alkyl in the SAMs was calculated from the frequency shifts by applying the Sauerbrey equation. After rinsing the quartz diskette with dichloromethane, the measured frequency variations are $475 \mathrm{ng} . \mathrm{cm}^{-2}$ and $301 \mathrm{ng} . \mathrm{cm}^{-2}$, corresponding to densities of $2.6 \times 10^{-10}$ and $2.15 \times 10^{-10} \mathrm{~mol} . \mathrm{cm}^{-2}$, which are close to reported values for fullerene compounds. ${ }^{[7,31]}$ These results suggest a higher density of molecules adsorbed on the surface with the $\mathbf{C}_{60}$-peptide. The lower $\mathbf{C}_{\mathbf{6 0}}$-alkyl SAM coverage compared to the $\mathbf{C}_{60}$-peptide SAM is consistent with the less dense monolayer observed by cyclic voltammetry and shows clearly that the peptide moiety allows the formation of a more densely packed layer.

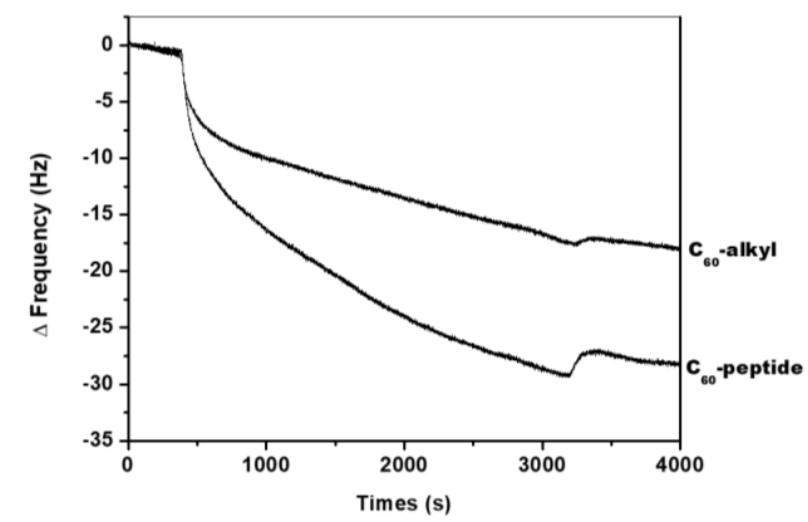


Figure 6. Resonance frequency changes of Au quartz crystal during $\mathbf{C}_{60}$-alkyl and $\mathbf{C}_{60}$-peptide SAMs formation; a $0.1 \mathrm{mM}$ solution of $\mathbf{C}_{60}$-alkyl and $\mathbf{C}_{60}$-peptide in dichloromethane was flowed for $55 \mathrm{~min}$.

X-Ray Photoelectron Spectroscopy (XPS) The C60-peptide and C60-alkyl SAMs on gold were characterized using XPS to assess the SAMs composition and the bonds with the gold surface. The XPS spectrum of the hexapeptide reference molecule $\mathbf{1 5}$ adsorbed on gold was also recorded to determine how the fullerene moiety influences the organization of the SAM. For the three samples, after SAM formation, the Au4f peak decreased in intensity while the $\mathrm{C} 1 \mathrm{~s}$, $\mathrm{O} 1 \mathrm{~s}, \mathrm{~N} 1 \mathrm{~s}$ and the S2p peaks appeared, indicating the presence of an additional layer on the surface. High resolution N1s and S2p XPS signals are shown in Figure 7. The N1s peak of the peptide azide terminated SAM presents four contributions at 400.0, 400.3, 401.3 and 404.4 \pm $0.1 \mathrm{eV}$. The major contribution at $400.0 \pm 0.1 \mathrm{eV}$ is attributed to $\mathrm{N}-\mathrm{H}$ amide groups of the peptide $(\sim 78 \%) .{ }^{[32]}$ The presence of the azide function is unambiguously revealed by the three other components at 400.3, 401.3 and $404.4 \pm 0.1 \mathrm{eV} \cdot{ }^{[33]}$ One can note here that the relative intensity ratio characteristics of the molecule $\mathrm{N}$-amide/ $\mathrm{N}$-azide is equal to 3.5 , above the expected value (2.3). It can be explained by partial decomposition upon X-ray radiation of the azide moiety, leading to a contribution at lower bonding energy probably included in the amide contribution at $400 \mathrm{eV} .^{[33]}$

In the case of the $\mathbf{C}_{60}$-peptide or $\mathbf{C}_{60}$-alkyl SAMs, the N1s peaks are best fitted with three contributions. The main contribution at $399.9 \pm 0.1 \mathrm{eV}$ is assigned to the $\mathrm{N}-\mathrm{H}$ of the amide, to the $\mathrm{O}=\mathrm{C}-\underline{\mathrm{N}}-$ of the maleimide or to the $\mathrm{N}-\underline{\mathrm{N}}-\mathrm{C}$ of the triazole. The two contributions at higher binding energy at $400.6 \mathrm{eV}$ and $401.8 \mathrm{eV} \pm 0.1 \mathrm{eV}$ in an approximate 1:1 ratio, are attributed to the triazole $\underline{\mathrm{N}}=\mathrm{N}-\mathrm{N}-\mathrm{C}$ and $\mathrm{N}=\underline{\mathrm{N}}-\mathrm{N}-\mathrm{C}$, respectively, showing that the molecules were intact when adsorbed on the gold surface. To explore the binding mode of the molecules on the gold surfaces the S2p signals were recorded. The S2p signals of the two SAMs with a peptide moiety are very similar and are best fitted with four $\mathrm{S} 2 \mathrm{p}_{3 / 2,1 / 2}$ doublets. The first two doublets at lower binding energy e.g. $161.1 \pm 0.1 \mathrm{eV}$ (green) and $162.0 \pm 0.1 \mathrm{eV}\left(\mathrm{S} 2 \mathrm{p}_{3 / 2}\right)$ (blue) are characteristic of multi-coordinated sulfur bonds to the gold surface and thiolate-gold bonds, respectively. ${ }^{[34]}$ In the two SAMs, a third $\mathrm{S} 2 \mathrm{p}$ signal at $163.6 \mathrm{eV} \pm 0.1 \mathrm{eV}$ (orange) is present, attributed to disulfide sulfur atoms, suggesting that a fraction of the disulfide groups are not bonded to the surface despite the intensive rinsing of the samples. ${ }^{[34-35]}$ Also, a broad S2p peak showing a significant presence of unbound sulfur was systematically observed in XPS for the helical peptide adsorbed on gold. ${ }^{[36]}$ Finally, a small doublet at high binding energy, $168.1 \pm 0.1$ $\mathrm{eV}$ (red) is characteristic of oxidized sulfur. The presence of unbound disulfide can originate from different species in the SAMs. In the case of fullerene derivative SAMs, the strong attraction between fullerene $\mathrm{C}_{60}$ units and the gold surface can produce head-to-tail arrangements and disorganised multi-layers. ${ }^{[10]}$ However, the unbound disulfide proportion in the S2p signal is of the same order of magnitude in the hexapeptide $\mathbf{1 5}$ and $\mathbf{C r o - p e p t i d e ~ S A M s ~}$ as shown in Table 1.This finding indicates that head to tail arrangements of $\mathbf{C}_{60}$-peptide are not likely to be the major contribution of unbound thiols. The presence of unbound thiol in the peptide and C60-peptide SAMs could originate from lateral interactions between peptides chains or fullerene-fullerene contacts that hamper binding of the thiol to the gold surface. 
Table 1. XPS Sulfur contributions comparison for hexapeptide 15, $\mathbf{C}_{60}$-peptide and $\mathbf{C}_{60}$-alkyl SAMs on gold.

\begin{tabular}{|l|l|l|l|}
\hline S2p components & Hexapeptide 15 & C60-peptide & C60-alkyl \\
\hline \% S bound & 48.5 & 47.6 & 73.3 \\
\hline \% S unbound & 37.4 & 36.9 & 26.7 \\
\hline \% S oxidized & 14.1 & 15.5 & \\
\hline
\end{tabular}
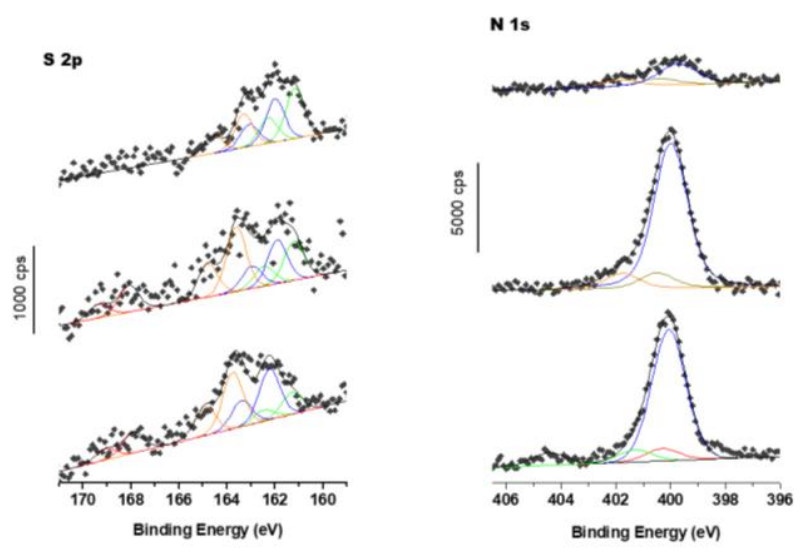

Figure 7. High resolution $\mathrm{S} 2 \mathrm{p}$ and $\mathrm{N} 1 \mathrm{~s}$ XPS spectra of $\mathbf{C}_{60}$-alkyl, $\mathbf{C}_{60}$-peptide and hexapeptide 15 SAMs (from the top to the bottom).

Polarization Modulation Reflection Adsorption InfraRed Spectroscopy (PM-RAIRS) Information on the orientation and order of molecules in the three SAMs (hexapeptide 15, $\mathbf{C}_{60}$ peptideand the $\mathbf{C}_{60}$-alkyl SAMs) were then probed by PM-RAIRS. First, the general spectroscopic profiles for the two molecules either as bulk, recorded by IR-ATR, or after assembly on gold, probed by PM-RAIRS, are shown in the Figures S23-25. ATR and PMRAIRS profiles are comparable, which suggests successful adsorption on the gold surface. In the three cases, there is a quite good agreement between both spectra, and the differences observed can be explained by the specificity of both IR techniques. While ATR provides information from the bulk, the RAIRS experiments, that follow metal surface selection rules (MSSR), ${ }^{[37]}$ imply that absorption bands with a transition moment perpendicular to the surface are enhanced, whereas parallel modes experience the opposite effect. The PM-RAIRS spectrum of the hexapeptide 15 adsorbed on gold is shown in Figure 8. The band at $2093 \mathrm{~cm}^{-1}$, characteristic of the azide moiety, confirmed the formation of the hexaptide $15 \mathrm{SAM}^{\left[{ }^{[38-39]}\right.}$ The spectrum is dominated by the amide I and II bands at 1658 and $1542 \mathrm{~cm}^{-1}$ respectively characteristic of a helical peptide. ${ }^{[26 a]}$ The upshift of the amide I band on the SAM compared to the bulk (Figures S24-25) can be attributed to vibrational coupling between amide groups of 
nearby helices. ${ }^{[40]}$ This suggests the formation of a relatively dense monolayer of molecules on the surface. The C60-peptide SAM PM-RAIRS spectra highlight the amide I and II vibration bands at very similar wave-numbers than in the case of the hexaptide 15 SAM, suggesting the formation of a similar dense layer on the surface, and confirming the dense layer observed by cyclic voltammetry.

Additional bands characteristic of the C60-peptide molecule are also present. Three bands characteristics of the $\mathrm{C}_{60}$ malonate at 1740,1267 and $1181 \mathrm{~cm}^{-1}$ are clearly seen in the spectrum. ${ }^{[41]}$ The bands at 1740 and $1267 \mathrm{~cm}^{-1}$ correspond to the malonate $\mathrm{C}=\mathrm{O}$ and $\mathrm{C}-\mathrm{O}$ stretching, respectively, while the band at $1181 \mathrm{~cm}^{-1}$ can be assigned to the $\omega_{3} \mathrm{C}_{60}$ cage vibration. ${ }^{[7]}$ Other bands characteristic of the maleimide and triazole groupments of the $\mathbf{C}_{60}$ peptide molecule are visible in the spectra and summarized in Table S1. The PM-RAIRS spectrum of the $\mathbf{C}_{60}$-alkyl SAM highlights all the same bands characteristic of the molecule as in the C60-peptide SAM, with some difference in intensity. The Amide I and II bands at 1644 and $1542 \mathrm{~cm}^{-1}$ are not as intense as in the spectrum of the $\mathbf{C}_{60}$-peptide SAM, due to the presence of only one amide group in the $\mathbf{C}_{60}$-alkyl molecule. A careful analysis of the amide I and II bands absorbance ratio in the SAMs involving the peptide, using a distribution function model, shows that the tilt angles of the helix axis from the surface normal are calculated to be 48.5 and $37.4 \pm 2^{\circ}$ for the hexapeptide $\mathbf{1 5}$ and $\mathbf{C}_{60}$-peptide SAMs, respectively. The tilt angle of the peptide SAM is very close to the tilt angle reported in the literature for a short chain peptide ( $49^{\circ}$ for a peptide containing the [Ala-Aib] 4 sequence). ${ }^{[14,26 a, 42]}$ Surprisingly, the tilt angle of the $\mathbf{C 6 0}$-peptide SAM is closer to the tilt angle of a longer peptide $\left(36^{\circ}\right.$ for a peptide containing the $[\text { Ala-Aib }]_{16}$ sequence). This result suggests that interactions between the fullerene units are added to the interactions between the short peptides, leading to intermolecular interactions that can be assimilated to the stronger intermolecular interactions of longer peptides, which finally result in a more vertical orientation. ${ }^{[42]}$ Interestingly, the presence of the $\mathrm{C}_{60}$ moiety increases the density of the monolayer compared to the hexapeptide $\mathbf{1 5}$ since the $\mathbf{C}_{60}$-peptide SAMs are more highly packed than the peptide SAMs. ${ }^{[43]}$

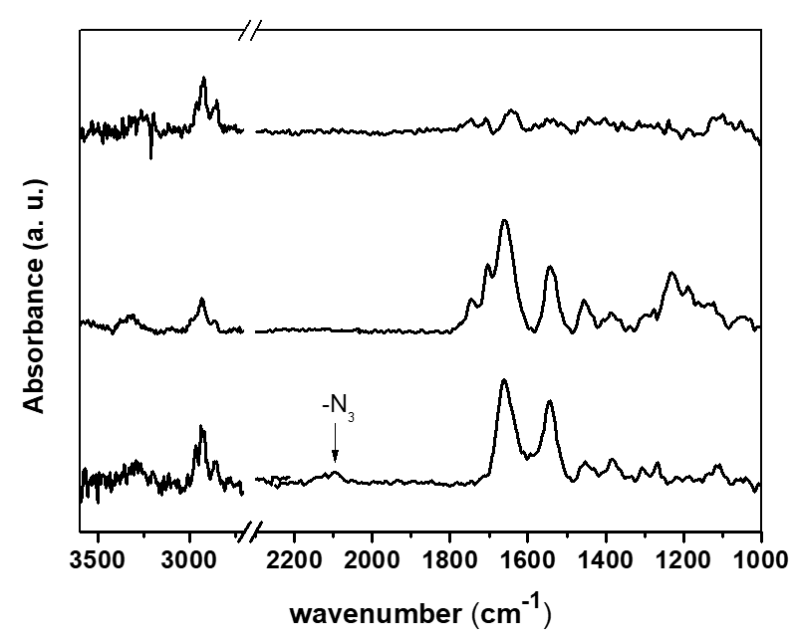

Figure 8. PM-RAIRS spectra of the $\mathbf{C}_{60}$-alkyl, $\mathbf{C}_{60}$-peptide and hexapeptide 15 SAMs. (from top to bottom) 


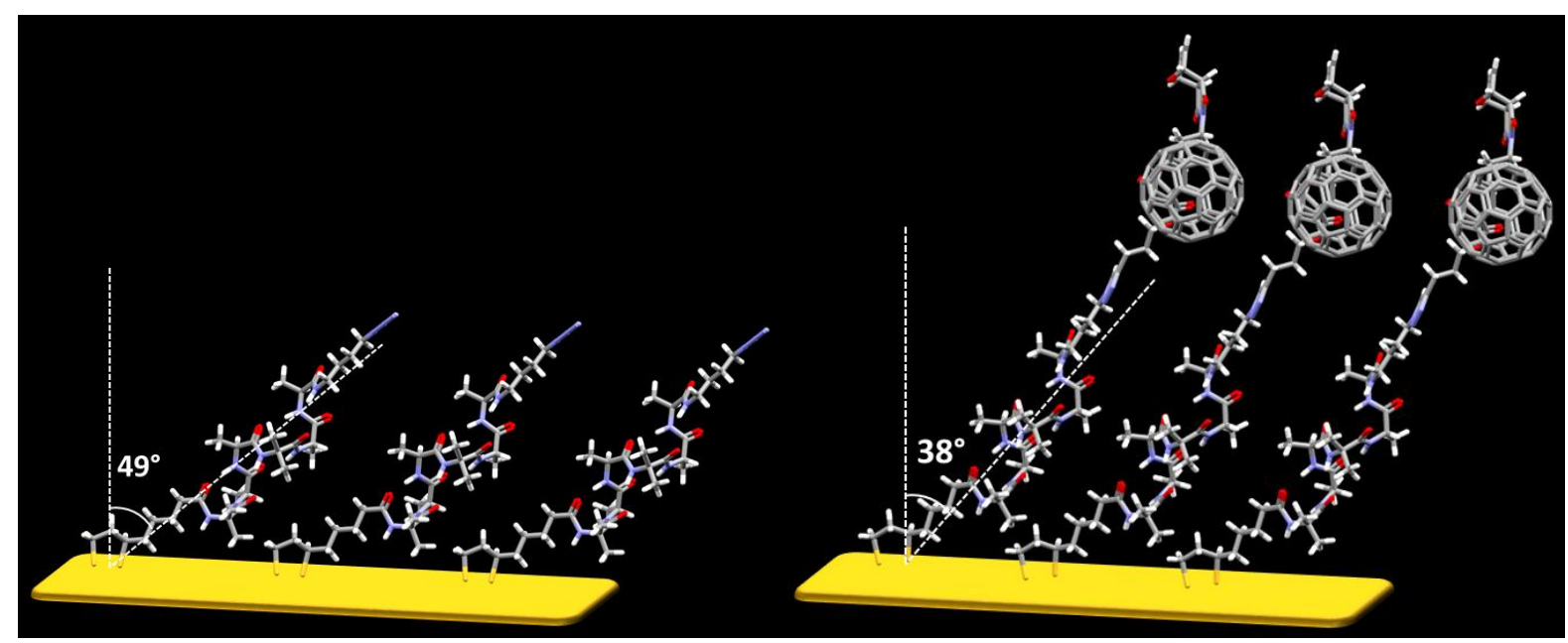

Figure 9. Schematic representation of SAMs of the hexapeptide $\mathbf{1 5}$ and $\mathbf{C}_{60}$-peptide adopting a 310 -helical conformation along with the tilt angles of the helices from the surface normal.

\section{Conclusion}

In summary, we have prepared a fullerene-terminated helical peptide and a fullerenealkyl derivative through the use of copper-catalyzed alkyne-azide cycloaddition reactions. The peptide azide and alkyl azide were grafted on a fullerene platform that bears on one side an alkyne unit, and a protected maleimide moiety on the other, allowing further functional modification. ${ }^{[15]}$ A copper (I) source based on the preformed complex [Cu(I)ligand (Hexabenzyl)Tren)]Br, prepared from $\mathrm{CuBr}$ and the hexabenzylTren ligand, was used for this reaction, and led to $40 \%$ and $60 \%$ yields for th e $\mathbf{C}_{60}$-alkyl and $\mathbf{C}_{60}$-peptide, respectively. This approach allowed the preparation of a significant amount of these derivatives, in particular the C60-peptide, and appears higher yielding than the previously reported strategy. ${ }^{[14]}$ The solution conformation analysis by IR absorption, NMR and circular dichroism measurements, of the starting hexapeptide and $\mathbf{C}_{60}$-peptide confirmed their helical conformation, likely a 310 -helical structure from NMR experiments. In addition, the starting hexapeptide, $\mathbf{C}_{60}$-alkyl and $\mathbf{C}_{60}$ peptide were designed with a lipoyl moiety at the end of the alkyl chain or the peptide $\mathrm{N}$ terminus, that allowed their grafting on a gold surface. The XPS and PM-RAIRS data showed that monolayers of these derivatives could be successfully prepared, and their self-assembling properties were studied and compared using surface characterization and electrochemical measurements. The beneficial effect of the peptide on SAMs formation was also confirmed. The helical C60-peptide allowed the formation of well-packed fullerene SAMs compared to the $\mathbf{C}_{60}$-alkyl, as determined from the coverage rate obtained by QCM and the difference of intensity of $\mathrm{CV}$ responses of the $\mathrm{Fe}(\mathrm{CN})_{6}{ }^{3-/ 4}$ redox probe. As well as demonstrating the contribution of the peptide for the formation of a denser fullerene layer, the comparison of angles obtained from the PM-RAIRS measurements indicated that the Co-peptide tended to be more vertical than the parent hexapeptide. This finding confirms the starting assumption that the organization within the monolayers is governed both by fullerene interactions and peptide interactions.

We currently envision using the electron mediator properties of the helical peptides along with their organising properties in fullerene-terminated peptide SAMs for organic 
electronic applications. In particular, we are planning to graft a donor-fullerene dyad on the helical peptide in order to develop photoelectrochemical devices. In such systems, the use of a short peptide, as used in this study, able to assume a helical conformation should be beneficial since the rate of electron transfer exponentially decreases with increasing distance of the photoand electro-active units from the metal surface. The length of the short peptide should also be sufficient not only to diminish quenching of the photo-excited chromophores by energy transfer from the gold surface, but also to reduce charge recombination processes. In addition, the strongly directional character of electron transfer through the peptide chain could also be exploited with fullerene-based SAMs for the design of molecular rectifiers.

\section{Experimental section}

The synthesis of compounds 1-15, $\mathbf{C}_{\mathbf{6 0}}$-alkyl and $\mathbf{C}_{\mathbf{6 0}}$ peptide as well as experimental details for SAMs formation and characterization are described in the supporting information. The NMR spectra of hexapeptide $\mathbf{1 5}$ and $\mathbf{C}_{60}$-peptide are depicted in Figures S3-S21. The IR spectra of hexapeptide $\mathbf{1 5}$ and $\mathbf{C}_{60}$-peptide in $\mathrm{CDCl}_{3}$ solution, in ATR and on gold surfaces are depicted in Figures S1-S2 and S23-S25. The CD spectrum of hexapeptide 15 is also provided in Figure S22.

\section{Acknowledgements}

This work was supported by CHARMMMAT ANR-11-LABX-0039-grant for the post-doctoral fellowhips to HN and VB-T-T. JR thanks the «Ministère de l'Enseignement Supérieur de la Recherche et de l'Innovation » for the $\mathrm{PhD}$ fellowship.

\section{Conflict of interest}

There are no conflicts of interest to declare.

\section{References}

[1] J.-F. Nierengarten, Top. Curr. Chem., 2003, 228, 87-110.

[2] D. Bonifazi, O. Enger and F. Diederich, Chem. Soc. Rev., 2007, 36, 390-414.

[3] S. K. Hau, Y.-J. Cheng, H.-L Yip, Y. Zhang, H. Ma and A. K.-Y. Jen, ACS Appl. Mat. Interfaces, 2010, 2, 1892-1902.

[4] a) T. Schmaltz, A. Khassanov, H.-G. Steinrück, A. Margel, A. Hirsch and M. Halik, Nanoscale, 2014, 6, 13022-13027; b) G. V. Dubacheva, M. Devynck, G. Raffy, L. Hirsch, A. Del Guerzo and D. M. Bassani, Small, 2014, 10, 454-461.

[5] L. Qiu, Y. Zhang, T. L. Krijger, X. Qiu, P. van't Hof, J. C. Hummelen and R. C. Chiechi, Chem. Sci., 2017, 8, 2365-2372.

[6] a) H. Imahori and S. Fukuzumi, Adv. Funct. Mater., 2004, 14,525-536; b) K.-S. Kim, M.S. Kang, H. Ma and A. K. Y. Jen, Chem. Mater., 2004, 16, 5058-5062; c) C. Y. Lee, J. K. 
Jang, C. H. Kim, J. Jung, B. K. Park, J. Park, W. Choi, Y.-K. Han, T. Joo and J. T. Park, Chem. Eur. J., 2010, 16, 5586-5599.

[7] M. Hosseini, D. M. Rivera-Nazario and L. A. Echegoyen, ACS Appl. Mater. Interfaces, 2014, 6, 3712-3720.

[8] a) H. Imahori, T. Azuma, S. Ozawa, H. Yamada, K. Ushida, A. Ajavakom, H. Norieda and Y. Sakata, Chem. Commun., 1999, 557-558; b) H. Imahori, T. Azuma, A. Ajavakom, H. Norieda, H. Yamada and Y. Sakata, J. Phys. Chem. B, 1999, 103, 7233-7237; c) T. Gu, J. K. Whitesell and M. A. Fox, J. Org. Chem., 2004, 69, 4075-4080; d) A. S. Viana, S. Leupold, C. Eberle, T. Shokati, F.-P. Montforts and L. M. Abrantes, Surf. Sci., 2007, 601, 5062-5068; e) Y. Shirai, J. M. Guerrero, T. Sasaki, T. He, H. Ding, G. Vives, B.-C. Yu, L. Cheng, A. K. Flatt, P. G. Taylor, Y. Gao and J. M. Tour, J. Org. Chem., 2009, 74, 78857897; f) M. del Carmen Gimenez-Lopez, M. T. Räisänen, T. W. Chamberlain, U. Weber, M. Lebedeva, G. A. Rance, G. A. D. Briggs, D. Pettifor, V. Burlakov, M. Buck and A. N. Khlobystov, Langmuir, 2011, 27, 10977-10985; g) P. Piotrowski, J. Pawłowska, J. Pawłowski, L. J. Opuchlik, R. Bilewicz and A. Kaim, RSC Adv., 2014, 6, 64310-64318; h)M. V. Solano, E. A. Della Pia, M. Jevric, C. Schubert, X. Wang, C. van der Pol, A. Kadziola, K. Nørgaard, D. M. Guldi, M. B. Nielsen and J. O. Jeppesen, Chem. Eur. J.,2014, 20, 9918-9929.

[9] J. C. Love, L. A. Estroff, J. K. Kriebel, R. G. Nuzzo and G. M. Whitesides, Chem. Rev., 2005, 105, 1103-1169.

[10] Y. Shirai, L. Cheng, B. Chen and J. M. Tour, J. Am. Chem. Soc., 2006, 128, 13479-13489. [11] a) E. Gatto, A. Quatela, M. Caruso, R. Tagliaferro, M. De Zotti, F. Formaggio, C. Toniolo, A. Di Carlo and M. Venanzi, ChemPhysChem, 2014, 15, 64-68; b) S. Yasutomi, T. Morita, Y. Imanishi and S. Kimura, Science, 2004, 304, 1944-1947.

[12]X. Yang, A. Ebrahimi, J. Li and Q. Cui, Int. J. Nanomedecine, 2014, 9, 77-92.

[13] S. Jennepalli, S. G. Pyne and P. A. Keller, RSC Adv., 2014, 4, 46383-46398.

[14]H. Uji, K. Tanaka and S. Kimura, J. Phys. Chem. C, 2016, 120, 3684-3689.

[15] a) C. Constant, S. Albert, N. Zivic, K. Baczko, H. Fensterbank and E. Allard, Tetrahedron, 2014, 70, 3023-3029; b) H. Fensterbank, K. Baczko, C. Constant, N. Idttalbe, F. Bourdreux, A. Vallée, A.-M. Goncalves, R. Méallet-Renault, G. Clavier, K. Wright and E. Allard, J. Org. Chem., 2016, 81, 8222-8233.

[16] a) I.L. Karle and P. Balaram, Biochemistry, 1990, 29, 6747-6755; b) B. Pispisa, L. Stella, M. Venanzi, A. Palleschi, C. Viappiani, A. Polese, F. Formaggio and C. Toniolo, Macromolecules,2000, 33, 906-915; c) G. Bocchinfuso, P. Conflitti, S. Raniolo, M. Caruso, C. Mazzuca, E. Gatto, E. Placidi, F. Formaggio, C. Toniolo, M. Venanzi and A. Palleschi, J. Pept. Sci., 2014, 20, 494-507.

[17] I. Nierengarten and J.-F. Nierengarten, Chem. Rec., 2015, 15, 31-51.

[18] R. Srinivasan, L. P. Tan, H. Wu, P.-Y Yang, K. A. Kalesh and S. Q. Yao, Org. Biomol. Chem., 2009, 7, 1821-1828.

[19] M. M. Kose, S. Onbulak, I. I. Yilmaz and A. Sanyal, Macromolecules, 2011, 44, 27072714.

[20]L. Liang, J. Ruiz and D. Astruc, Adv. Synth. Catal., 2011, 353, 3434-3450.

[21]T. R. Chan, R. Hilgraf, K. B. Sharpless and V. V. Fokin, Org. Lett., 2004, 6, 2853-2855. 
[22] We have noticed that the fullerene derivatives containing lipoic acid led to the formation of by-products detected by TLC after standing for several weeks in the solid state or after several hours in oxygenated solution. These by-products, that have been identified by mass spectrometry, could result from the photosensitized oxidation of the lipoic acid unit leading to the formation of thiosulfinates and thiolsulfonates. ${ }^{[23]}$ The fullerene unit acts as a photosensitizer and triggers the formation of singlet oxygen that promotes the oxidation of the lipoic moiety.

[23] E. F. Stary, S. L. Jindal and R. W. Murray, J. Org. Chem., 1975, 40, 58-62.

[24] A. Polese, S. Mondini, A. Bianco, C. Toniolo, G. Scorrano, D. M. Guldi and M. Maggini, J. Am. Chem. Soc., 1999, 121, 3446-3452.

[25] M. De Zotti, K. Wright, E. D’Aboville, A. Toffoletti, C. Toniolo, G. Longhi, G. Mazzeo, S. Abbate and F. Formaggio, J. Org. Chem., 2017, 82, 10033-10042.

[26] a) K. Yanagisawa, T. Morita and S. Kimura, J. Am. Chem. Soc.,2004, 126, 12780-12781; b) L. Garbuio, S. Antonello, I. Guryanov, Y. Li, M. Ruzzi, N. J. Turro and F. Maran, J. Am. Chem. Soc., 2012, 134, 10628-10637; c) N. Ousaka, F. Mamiya, Y. Iwata, K. Nishimura and E. Yashima, Angew. Chem. Int. Ed., 2017, 56, 791-795.

[27] S. J. Pike, V. Diemer, J. Raftery, S. J. Webb and J. Clayden, Chem. Eur. J., 2014, 20, 15981-15990.

[28] a) M. Goodman, A. S. Verdini, C. Toniolo, W. D. Phillips and F. A. Bovey, Proceedings of the National Academy of Sciences, 1969, 64, 444-450; b) G. Holzwarth and P. Doty,J. Am. Chem. Soc., 1965, 87,218-228.

[29] E. Longo, A. Moretto, F. Formaggio andC. Toniolo, Chirality, 2011, 23, 756-760.

[30] a) M. Kai, K. Tadeka and S. Kimura, J. Pept. Sci., 2008, 14, 192-202; b) E. Gatto, M. Caruso, A. Porchetta, C. Toniolo, F. Formaggio, M. Crisma and M. Venanzi, J. Pept. Sci., 2011, 17, 124-131.

[31] W. B. Caldwell, K. Chen, C. A. Mirkin and S. J. Babinec, Langmuir, 1993, 9, 1945-1947.

[32] A. Vallée, V. Humblot, R. Al Housseiny, S. Boujday and C.-M. Pradier, Colloids Surf. B, 2013, 109, 136-142.

[33] T. Heinrich, C. H.-H. Traulsen, E. Darlatt, S. Richter, J. Poppenberg, N. L. Traulsen, I. Linder, A. Lippitz, P. M. Dietrich, B. Dib, W. E. S. Unger and C. A. Schalley, RSC Adv., 2014, 4, 17694-17702.

[34] E. Beford, V. Humblot, C. Méthivier, C.-M. Pradier, F. Gu, F. Tielens and S. Boujday, Chem. - Eur. J., 2015, 21, 14555-14561.

[35] D. G. Castner, K. Hinds, D. W. Grainger, Langmuir, 1996, 12, 5083-5086.

[36] a) M. Venanzi, G. Pace, A. Palleschi, L. Stella, P. Castrucci, M. Scarselli, M. De Crescenzi, F. Formaggio, C. Toniolo, G. Marletta, Surf. Sci., 2006, 600, 409-416; b) E. Longo, K. Wright, M. Caruso, E. Gatto, A. Palleschi, M. Scarselli, M. De Crescenzi, M. Crisma, F. Formaggio, C. Toniolo, M. Venanzi, Nanoscale, 2015, 7, 15495-15506.

[37] R. G. Greenler, D. R. Snider, D. Witt and R. S. Sorbello, Surf. Sci., 1982, 118, 415-428.

[38] P. Srivastava, M. Ghasemi, N. Ray, A. Sarkar, J. Kocabova, S. Lachmanova, M. Hromadova, S. Boujday, S. Cauteruccio, P. Thakare, E. Licandro, C. Fosse and M. Salmain, Appl. Surf. Sci., 2016, 385, 47-55.

[39] P. Srivastava, A. Sarkar, S. Sawoo, A. Chakraborty, P. Dutta and M. Salmain, J. Organomet. Chem., 2011, 696, 1102-1107. 
[40] E. Karjalainen and A. Barth, J. Phys. Chem. B, 2012, 116, 4448-4456.

[41] P. Damlin, M. Hätönen, A. E. Dominguez, T. Ääritalo, H. Kivelä and C. Kvarnström, RSC Adv., 2014, 4, 8391-8401.

[42] Y. Arikuma, H. Nakayama, T. Morita and S. Kimura, Angew. Chemie - Int. Ed., 2010, 49, 1800-1804.

[43] P. Gobbo, S. Antonello, I. Guryanov and F. Polo, ChemElectroChem, 2016, 3, 1-9. 